\title{
Expression of miRNA in obesity and insulin resistance: a review
}

\author{
Paulina Estrella-Ibarra', ${ }^{1}$, Pablo García-Solís ${ }^{2}$, Juan Carlos Solís-Sáinz², Andrés Cruz-Hernández ${ }^{3}$ \\ ${ }^{1}$ Department of Biomedical Sciences, Autonomous University of Queretaro, Prados de La Capilla, Queretaro, Mexico \\ ${ }^{2}$ School of Natural Sciences, Autonomous University of Queretaro, Juriquilla, Queretaro, Mexico \\ ${ }^{3}$ Agronomy school, De La Salle Bajio University, León, Guanajuato, México
}

\begin{abstract}
MicroRNAs (miRNAs) are part of the epigenetic mechanisms that regulate gene expression at a post-transcriptional level. This review describes some miRNAs whose expression is modified in obesity and that may be involved in the development of insulin resistance. The metabolic alterations associated with obesity are due to an adipose tissue dysfunction. miRNAs are a mechanism that regulates gene expression, one miRNA can regulate the expression up to a thousand genes, and at the same time one gene can be regulated by several miRNAs; moreover, miRNA expression is tissue specific. Obesity leads to a dysregulation of miRNA expression in adipose tissue, and changes in miRNA expression relate to changes in gene expression related to the development of insulin resistance. However, because miRNA can be exported to the extracellular medium through exosomes, proteins, and lipoproteins, miRNA can be found in extracellular fluids like blood, urine, saliva, and cerebrospinal fluid. Considering the above, miRNA have been proposed as biological markers of different diseases, and also as potential therapeutic targets. (Endokrynol Pol 2021; 72 (1): 73-80)
\end{abstract}

Key words: obesity; microRNA; insulin resistance; adipose tissue; epigenetics

\section{Introduction}

According to the World Health Organisation (WHO), overweight and obesity are defined as abnormal or excessive fat accumulation that may impair health [1]. In addition to the excess of fat accumulation, adipose tissue dysfunction is the cause of many metabolic alterations associated with obesity as insulin resistance (IR). Obesity leads to adipose tissue hypertrophy and hyperplasia. When the storage capacity of subcutaneous adipose tissue (SAT) adipocytes is exceeded, free fatty acids (FFA) accumulate in other organs, such as liver and skeletal muscle, favouring IR development [2]. Adipocyte hypertrophy promote the recruitment of circulating monocytes and activation of macrophages resident in adipose tissue, this favours proinflammatory cytokines such as tumour necrosis factor $\alpha(\mathrm{TNF} \alpha)$ and interleukin 6 (IL6) release, which in turn contribute to IR [3]. In addition, obesity causes dysregulation in the endocrine function of adipose tissue. Indeed, there is an increase in the expression and secretion of adipocytokines such as leptin, retinol binding protein 4 (RBP4), and resistin, which promote IR; while there is also a reduction in the expression of adiponectin, which promotes insulin sensitivity [4-6]. Molecular mechanisms related to adipose tissue dysfunction are unknown in detail; however, epigenetic mechanisms such as miRNAs could explain changes in genetic expression in adipose tissue that are associated with IR development.

\section{Obesity is the main factor related to IR}

Insulin resistance is characterised by a dysfunction of insulin action, which provokes an increment of its concentrations in order to maintain normal blood glucose. Moreover, IR is an important predisposing factor to the type 2 diabetes mellitus (T2DM) development [2]. White adipose tissue (WAT) is composed of adipocytes and the fraction of the vascular stroma, which in turn is composed of preadipocytes, endothelial cells, fibroblasts, macrophages, leukocytes, and nerve fibres [7]. According to its distribution, WAT is divided into SAT and visceral adipose tissue (VAT). SAT is found under the skin in the abdominal, femoral, and gluteal areas, while VAT is located around vital organs, and inside the peritoneum and the thoracic cage [7]. One of the major functions of WAT is the storage of excess energy in the form of triglycerides during feeding, as well as its release as FFA and glycerol during fasting. Obesity leads 
to a hypertrophy and to a lesser extent to a hyperplasia of the adipocyte. When the storage capacity of the adipocyte is exceeded, FFA accumulate in other organs and tissues leading to lipotoxicity. An increase in FFA causes beta cell dysfunction in the pancreas and favours IR development in the liver and skeletal muscles [8]. Otherwise, adipocyte hypertrophy decreases blood flow to some adipocytes, which undergo hypoxia and death by necrosis. This triggers an inflammatory response, and circulating monocytes infiltrate adipose tissue and transform into macrophages, which form "crown-like structures" around dead adipocytes. Macrophages produce proinflammatory cytokines like TNF $\alpha$ and IL6, which in turn contribute to IR development [9]. Obesity is also characterised by an alteration in the endocrine function of adipose tissue; there is also an increase in the expression of adipocytokines like leptin, TNF $\alpha$, IL6, resistin, visfatin, RBP4, and apelin, and a reduction of adiponectin expression; all these changes are related to IR development [10].

Currently, the molecular mechanisms explaining adipose tissue dysfunction associated with obesity are unknown. However, changes in gene expression could contribute to this pathological process, which leads to IR. Epigenetics is defined as heritable changes in gene expression without changes in the DNA sequence [11]. Epigenetic changes are reversible and are regulated by environmental factors such as diet, exercise, stress, alcohol consumption, smoking, and even factors such as the nutritional status of the mother. Among the epigenetic mechanisms are miRNA [11].-

\section{miRNAs are short single-stranded RNA molecules}

miRNAs are single-stranded RNA molecules, around 22 nucleotides in length, of endogenous expression, which regulate gene expression at a posttranscriptional level [12]. For a small RNA to be considered a miRNA, it must meet the following criteria: it must have a length of 19-25 nucleotides; it must come from a precursor (around 60-80 nucleotides) capable of forming hairpin structures; and finally miRNAs are phylogenetically conserved [12].

\section{miRNAs regulate the expression of a significant number of genes}

miRNA-codifying genes represent $1 \%$ of the human genome, and it is thought that the expression of approximately $30 \%$ of all genes is regulated by miRNAs $[13,14]$. A single miRNA can regulate the expression of up to a thousand genes, and one gene can be regulated by several miRNAs [15]. To date, 38,589 miRNAs have been identified, of which 2654 correspond to mature miRNAs in humans [16]. miRNA genes can be located in intronic and intergenic genomic positions, but most of them are found in intergenic regions. In humans, most of the miRNAs are transcribed as an independent transcriptional unit; however, some miRNAs are clustered in the genome and their transcription is regulated by the same promoter, so they are transcribed as a single polycistronic unit. miRNAs located in the intronic regions are released during splicing [12, 13].

\section{miRNA biogenesis}

miRNAs are transcribed as primary transcripts (pri-miRNA) by RNA pol II. pri-miRNAs have a length of several kilobases and a hairpin structure. Like messenger RNAs (mRNAs), miRNAs contain a 7-methyl-guanosine cap at the 5 'end and a 3'-poly-(A). Inside the nucleus, pri-miRNAs are processed by a microprocessor, which consists of the RNase III-type endonuclease Drosha and the DGCR8 protein, which helps Drosha to recognise the pri-miRNA. This process releases a 70-nucleotide stem-loop structure know as miRNA precursor (pre-miRNA) [12,17]. The pre-miRNA is exported to the cytosol by an exporting 5 protein and suffers a second processing by RNase III Dicer, initiating a double-strand mature miRNA with a length of around 22 nucleotides. Next, one of the mature miRNA strands is degraded while the other is loaded to an Argonaute protein, generating the miRNA-induced silencing complex (miRISC) [12, 13]. In humans, 4 subfamily members of the Argonaute protein have been identified (Ago 1-4), Ago2 being the only one with silencing activity [18]. The miRNA recognises, by base-pairing, a 3' UTR region of mRNA. Unlike plants, in which the base-pairing between miRNA-mRNA is almost perfect, in animals this interaction is given in a specific region of the miRNA called the "seed", corresponding to the $2-7$ or 2-8 nucleotides in the $5^{\prime}$ end. Via miRISC, the interaction between miRNA-mRNA leads to the inhibition of the mRNA transcript translation and or its degradation [12] (Fig. 1).

\section{miRNA function}

The mechanisms by which miRNA mediate mRNA decay and the repression of translation are not fully understood. The miRNA-mRNA interaction attracts several protein complexes that induce mRNA deadenylation and decapping, this leads to mRNA being exposed to nuclease degradation. mRNA decay is the most common way in which miRNAs control gene expression in mammalians cells. Translation can be repressed at the 


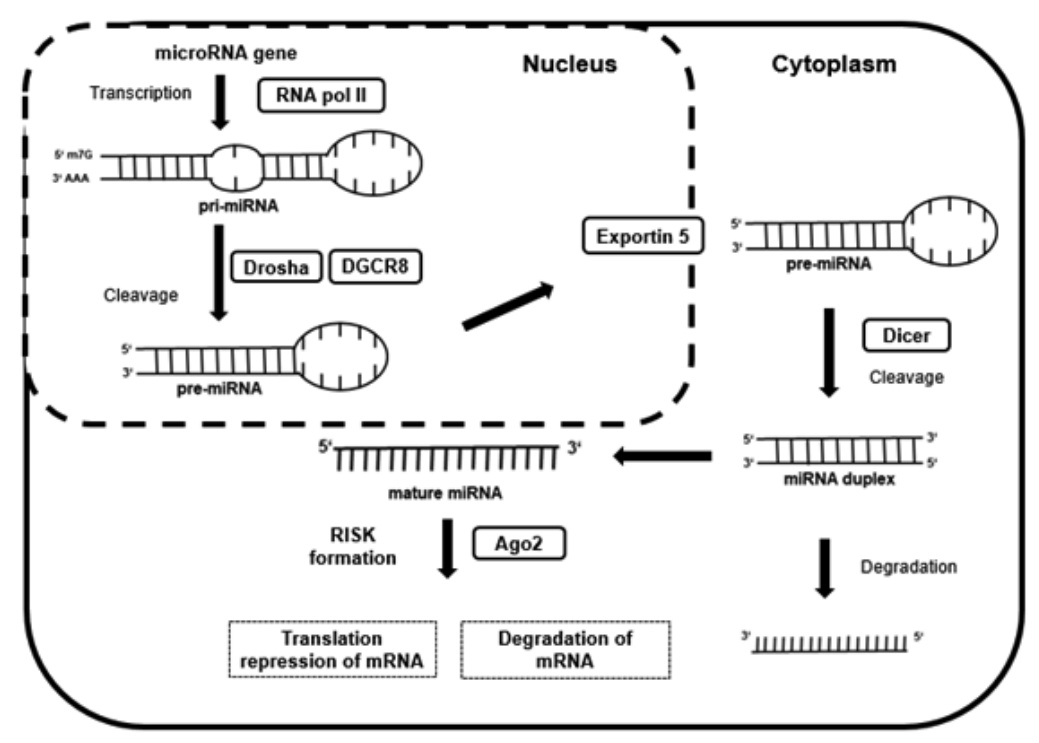

Figure 1. miRNAs biogenesis. miRNAs are transcribed as primary transcripts (pri-miRNA) by RNA pol II. Inside the nucleus, primiRNA is processed by the RNase III type endonuclease Drosha. This process releases a stem-loop structure know as miRNA precursor (pre-miRNA). The pre-miRNA is exported to the cytosol by an exportin 5 protein, and suffers a second processing by RNase III Dicer, giving rise to a double-strand mature miRNA with a length of around 22 nucleotides. Next, one of the mature miRNA strands is degraded while the other is loaded to Ago2, generating the miRNA-induced silencing complex (miRISC). Via miRISC, the interaction between miRNA-mRNA leads to the inhibition of the mRNA transcript translation and/or its degradation

initiation or during elongation, and in rare cases there may be a reduction of protein abundance without a decrease in the amount of the transcript $[19,20]$.

\section{miRNAs are associated with obesity and IR}

Obesity could lead to an altered expression of miRNAs, which is responsible for several metabolic alterations. Several studies have found differences in miRNA expression in adipose tissue, between lean and obese subjects. Table 1 summarises the miRNA differentially expressed in adipose tissue from obese subjects.

\section{Lethal-7 family (let-7)}

The lethal-7 (let-7) was original identified in C. elegans, and it was the first known human miRNA. Studies have demonstrated a reduction of some let-7 family members in the SAT of obese subjects [21].

The let-7 family of miRNAs plays a key role in modulating inflammatory responses. Brennan et al. [22] found a reduction of $\approx 30 \%$ in let-7d expression in mouse vascular smooth muscle cells (SMC) treated with $1 \mathrm{ng} / \mathrm{mL}$ of TNF $\alpha$ for $24 \mathrm{~h}$. Likewise, let-7d reduced the proinflammatory cytokines IL6 and IL1 $\beta$ expression and NF $\kappa \beta$ activity in TNF $\alpha$-treated SMC. These results were also confirmed in an ex-vivo transfection model in human carotid plaque tissue with let-7d resulting in a reduction of $\mathrm{TNF} \alpha, \mathrm{IL} 1 \beta, \mathrm{IFN} \gamma$, and the vascular cell adhesion molecule 1 (ICAM1) expression [22]. Sung et al. [23] transfected bone marrow-derived mesenchymal stem cells with let-7c as a representative miRNA of the let-7 family. Transfection of this miRNA resulted in the repression of IL6 expression and a reduction in their protein levels. These authors found that IL6 is a target gene of for the let-7 microRNA.

Obesity and T2DM are associated with a reduction in plasmatic levels of several members of the let-7 family of miRNA, such as let7-a, let-7c, let-7d, let-7e, let-7f, and let-7g [24, 25]. Also, Arner et al. [21] found a reduction of let-7a and let-7d expression in the SAT of obese subjects compared to lean subjects. Thus, the reduction of the let-7 family of miRNA expression in obesity and T2DM could lead to an increase of proinflammatory cytokines that promote IR.

\section{miR-193b}

Obesity is associated to a reduction of miR-193b expression. Diverse studies have demonstrated a decrease in expression of this miRNA in adipose tissue from obese subjects, compared to lean subjects [21,26]. Belarbi et al. [27] demonstrated that miR-193b overexpression induced greater adiponectin secretion in human SAT. Obesity is associated with a reduction of adiponectin plasmatic levels and also with a reduction in its expression in adipose tissue [28-30]. Adiponectin decreases IR in skeletal muscle by promoting FFA oxidation and also decreases the expression of gluconeogenic genes in liver [31,32]. Apparently, miR-193b represses the expres- 
Table 1. miRNA dysregulated in white adipose tissue (WAT) of obese humans

\begin{tabular}{|c|c|c|c|c|}
\hline Author & WAT depot & Groups of study & Upregulated miRNA & Downregulated miRNA \\
\hline $\begin{array}{l}\text { Martinelli et al. } \\
\text { (2010) [58] }\end{array}$ & SAT & $\begin{array}{l}\text { Control }(\mathrm{BMI}<30, \mathrm{n}=9) \\
\text { Obese }(\mathrm{BMI}>40, \mathrm{n}=10)\end{array}$ & miR-519d, miR-498, miR-150 & miR-659, miR-371-3p \\
\hline \multirow{4}{*}{$\begin{array}{l}\text { Ortega et al. } \\
\text { (2010) [38] }\end{array}$} & \multirow{4}{*}{ SAT } & \multirow{4}{*}{$\begin{array}{c}\text { Control }(\mathrm{BMI}<30, \mathrm{n}=6) \\
\text { Obese without T2DM }(\mathrm{BMI}>40, \mathrm{n}=13) \\
\text { Obese with T2DM }(\mathrm{BMI}>40, \mathrm{n}=7)\end{array}$} & \multicolumn{2}{|c|}{ Obese without T2DM vs. control } \\
\hline & & & $\begin{array}{l}\text { miR-185, miR-139-5p, } \\
\text { miR-484, miR-130b }\end{array}$ & $\begin{array}{l}\text { miR-221, miR-125b, miR-99a } \\
\text { miR-1229 }\end{array}$ \\
\hline & & & \multicolumn{2}{|c|}{ Obese without T2DM vs. obese with T2DM } \\
\hline & & & $\begin{array}{l}\text { miR-484, miR-130b, } \\
\text { miR-K12-7 }\end{array}$ & $\begin{array}{l}\text { miR-221, miR-125b, } \\
\text { miR-199a-5p, miR-1229 }\end{array}$ \\
\hline $\begin{array}{l}\text { Heneghan et al. } \\
\text { (2011) [60] }\end{array}$ & VAT & $\begin{array}{c}\text { Control }(\mathrm{BMI}<25, \mathrm{n}=10) \\
\text { Obese }(\mathrm{BMI}>40, \mathrm{n}=19)\end{array}$ & - & miR-17-5p, miR-132 \\
\hline $\begin{array}{l}\text { Arner et al. } \\
\text { (2012) [21] }\end{array}$ & SAT & $\begin{array}{l}\text { Control }(\mathrm{BMI}<30, \mathrm{n}=20) \\
\text { Obese }(\mathrm{BMI}>30, \mathrm{n}=30)\end{array}$ & - & $\begin{array}{l}\text { miR-26a, miR-92a, miR-30c, } \\
\text { miR-126, miR-143, miR-145, } \\
\text { miR-193a-5p, miR-652, } \\
\text { miR-let7a, miR-let 7d }\end{array}$ \\
\hline $\begin{array}{l}\text { Meerson et al. } \\
2013[26]\end{array}$ & SAT & $\begin{array}{l}\text { Control }(\mathrm{BMI}<30, \mathrm{n}=9) \\
\text { Obese }(\mathrm{BMI}>37, \mathrm{n}=10)\end{array}$ & $\begin{array}{l}\text { miR-221, miR-146a, miR-494, } \\
\text { miR-146b }\end{array}$ & $\begin{array}{l}\text { miR-139, miR-193a, } \\
\text { miR-193b-5p, miR-500 }\end{array}$ \\
\hline $\begin{array}{l}\text { Liu et al. } \\
2016 \text { [57] }\end{array}$ & VAT & $\begin{array}{l}\text { Control }(\mathrm{BMI}<30, \mathrm{n}=6) \\
\text { Obese }(\mathrm{BMI}>30, \mathrm{n}=6)\end{array}$ & & miR-1934 \\
\hline $\begin{array}{l}\text { Deiuliis et al. } \\
2016 \text { [51] }\end{array}$ & VAT & $\begin{array}{l}\text { Control }(\mathrm{BMI}<25, \mathrm{n}=21) \\
\text { Obese }(\mathrm{BMI}>25, \mathrm{n}=14)\end{array}$ & miR-223 & \\
\hline
\end{tabular}

BMI — body mass index [kg/m²]; T2DM — type 2 diabetes mellitus; SAT — subcutaneous adipose tissue; VAT — visceral adipose tissue; WAT — white adipose tissue

sion of a subunit of the nuclear transcription factor $\gamma$ $(\mathrm{NF}-\gamma)$, which decreases the activity of the adiponectin promoter activity nearly by $20 \%[27,33]$.

It has also been demonstrated that miR-193b regulates the expression of IL6. IL6 induces IR in liver and adipose tissue. This cytokine acts by a JAK/STAT3 signalling pathway that impairs insulin receptor substrate 1 (IRS-1) phosphorylation and induces its degradation, leading to a disruption in insulin signalling [34, 35]. Interleukin 6 also promotes IR by inducing adipose tissue lipolysis [36]. miR-193b overexpression in human subcutaneous adipocytes attenuates IL6 secretion [21]. Another gene regulated by miR-193b is the chemokine (C-C motif) ligand 2 (CCL2), also referred to as monocyte chemoattractant protein 1 (MCP-1). CCL2 is a chemokine produced in adipose tissue that triggers the infiltration of circulating monocytes, activating the inflammatory response responsible for IR [37]. miR-193b decreases CCL2 secretion from human subcutaneous adipocytes. Although CCL2 is not a direct target of miR-193b, it has been shown that this miRNA regulates the expression of this chemokine by regulating the expression of transcription factors, which in turn regulate its expression [27]. Thus, the reduction of miR-193b expression associated with obesity leads to a decrease in adiponectin expression and to an increase in IL6 and CCL2 expression, leading to the development of IR.

\section{miR-221 family}

The miR-221 family is composed of two members: miR-221 and miR-222, and the expression of both miRNA is associated with obesity [21, 26, 38]. There is a direct relationship between BMI and miR-221 expression in adipose tissue. Obese subjects have an increase in miR-221 expression in SAT, compared to normal weight subjects [38]. It has been reported that there is a decrease in miR-221 expression in SAT of obese subjects who suffer an important weight loss after surgery [39]. However, Prats-Puig et al. [40] found a miR-221 decrease in the plasma of obese children, compared to normal weight children. Also, Ortega et al. [41] showed that morbidly obese subjects have a decrease in the plasma miR-221. In the same study, these authors found that weight loss leads to an increase in plasmatic levels of miR-221 [40]. Conversely, Wang et al. [42] showed an increase in serum levels of miR-221 in women with metabolic syndrome, compared to controls. Interestingly, miR-221 is overexpressed in adipose tissue from obese subjects, while apparently their circulating levels are lowered compared to nor- 
mal-weight subjects. Although it is clear that obesity is associated to a dysregulation of miR-221 expression, future research needs to be focused in explaining the differences between what is found in adipose tissue and circulating levels. This could clarify the potential role of miR-221 as a clinical marker of metabolic disease. Moreover, miR-221 is associated with IR via controlling the expression of the adiponectin receptor-1 (ADIPOR1). There are two adiponectin receptors: ADIPOR1 and ADIPOR2. ADIPOR1 is expressed ubiquitously, whereas ADIPOR2 is expressed mainly in liver [43]. miRNA-221 is directly downregulated by ADIPOR1, but not by ADIPOR2. According to Meerson et al. [26], transfection to HEK293 cells and human preadipocytes with miR-221 mimics resulted in a reduction of ADIPOR1 protein levels without alterations in its mRNA. These results are in agreement with those reported by Lustig et al. [44], in which overexpression of miR-221 in HepG2 cells decreased ADIPOR1 protein levels, without ADIPOR1 mRNA changes. Sirtuin 1 (SIRT1) is another direct target of miR-221 [45]. SIRT1 belongs to the histone deacetylases that depend on the NAD+ family. The expression of this protein promotes an increase of insulin sensitivity in adipose tissue, increasing adiponectin expression and decreasing the expression of some proinflammatory cytokines such as IL6, TNF $\alpha$, CCL2, JNK, and IL1 $\beta$ $[46,47]$. Low chronic inflammation is a characteristic of obesity, and it is closely related to IR. On the other hand, it has been demonstrated that inflammation plays an important role in the regulation of miR-221 expression. Using the media of pro-inflammatory M1-like phenotype macrophage with liposaccharide (LPS), Ortega et al. [39] demonstrated that inflammation induces an increase in miR-221 expression in human mature adipocytes. Peng et al. [45] showed that treatment with $10 \mathrm{ng} / \mathrm{mL}$ of TNF $\alpha$ for $24 \mathrm{~h}$ in 3T3-L1 adipocytes resulted in miR-221 overexpression. These results differ from those reported by Meerson et al. [26], in which the authors showed that in preadipocytes 3T3-L1 treatment with leptin (at concentrations of 50,200 , and $500 \mathrm{ng} / \mathrm{mL}$ ) or TNF $\alpha$ (at 5 and $500 \mathrm{ng} / \mathrm{mL}$ ) for $24 \mathrm{~h}$ downregulates the miR-221 expression. Further studies are needed to elucidate the effect of inflammation in the regulation of miR-221 expression, whose effect probably differs from the preadipocyte to the mature adipocyte.

miR-222 is implicated in the regulation of insulin sensitivity. Transfection of miR-222 in 3T3-L1 cells decrease GLUT4 expression, while the silencing of this miRNA reduces insulin-stimulated glucose uptake by $\approx 40 \%$ [48]. GLUT4 expression is an indicator of the adipocyte response to insulin action. Obesity and
T2DM are associated with SAT GLUT4 expression reduction [49].

\section{miR-223}

miR-223 is associated with regulation of glucose homeostasis and inflammatory response [50,51]. Chuang et al. [50] demonstrated that miR-223 is overexpressed in SAT from women with IR. The overexpression of this miRNA in human adipocytes inhibits glucose uptake stimulated by insulin, and it also decreases protein abundance of GLUT4 without an effect on the transcript abundance. Deiuliis et al. [51] found that miR-223-3p is upregulated in human VAT from obese subjects. According to these authors, the upregulation of this miRNA expression is specific to the stromal vascular cells of human VAT. miR-223 plays a role in macrophage infiltration to adipose tissue, by controlling the expression of the Toll-like receptor 4 (TLR4) [51]. Obesity leads to an increase of FFA from the diet or adipose tissue lipolysis. The TLR4 is activated by FFA, which promotes downstream $\mathrm{NF}-\kappa \beta$ signalling, leading to the expression of several chemokines, such as CCL2 [37].

\section{miR-130}

The miR-130 family consists of four members; miR-130a, miR-130b, miR-301a, and miR-301b. Studies show that the expression of miR-130a and miR-130b is repressed in the SAT of obese subjects, and that they have as a direct target the peroxisome proliferator-activated receptor $\gamma$ $(\operatorname{PPAR} \gamma)[38,52]$.

PPAR $\gamma$ is a transcription factor known as the master regulator of adipogenesis. The activation of PPAR $\gamma$ represses the expression of proinflammatory genes $\operatorname{TNF} \alpha$, IL6, and IL1 $\beta$, and it up-regulates adiponectin expression [53]. In obese subjects there is an increase in PPAR $\gamma$ expression in SAT; however, the expression of this transcription factor is reduced in obese subjects with metabolic alterations [54, 55]. Changes in PPAR $\gamma$ expression can act as an adaptive mechanism at the onset of obesity, and its expression can be affected by other metabolic alterations [55].

\section{Other miRNA families}

The miR-378 family consists of five members, and overexpression of one family member has been reported in SAT in obese individuals. The adiponectin gene is a direct target of miR-378 [38, 56].

miR-1934 is repressed in VAT of obese individuals, and this miRNA inhibits IL6, IL1b, and CCL2 expression [57]. Resistin is another target of miR-1934; serum 


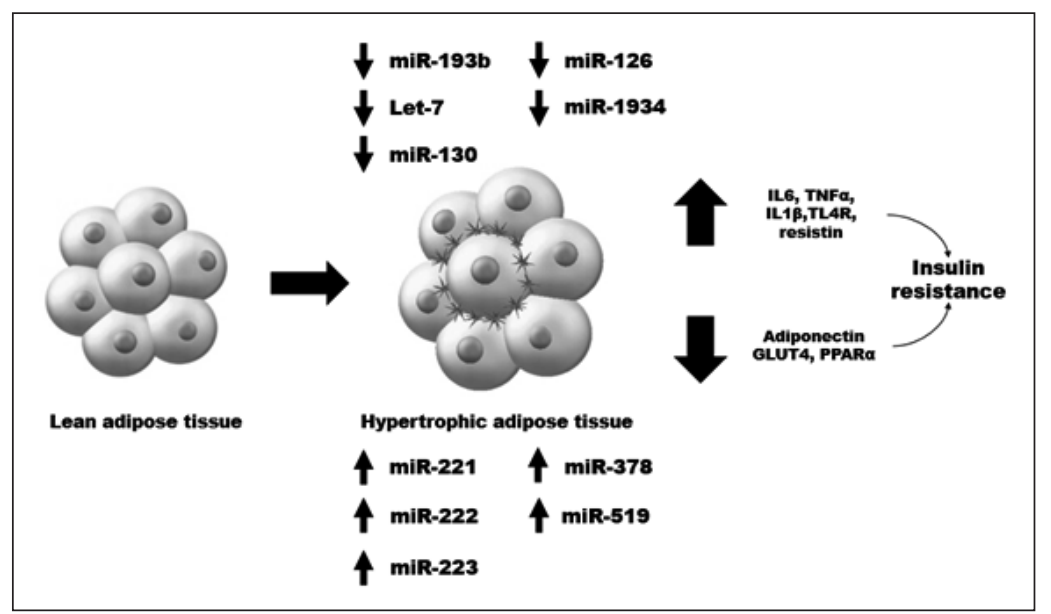

Figure 2. Changes in miRNA expression in adipose tissue of obese subjects and their relationship with IR development. Adipose tissue hypertrophy is associated with changes in miRNA expression, overexpression of miR-221, miR-221, miR-223, miR-378, and miR-519 and repression of let7, miR-193b, miR-130, miR-126, and miR-1934. These changes result in an increase of proinflammatory cytokines expression and reduction of adiponectin and GLUT4 expression, this leads to the development of IR

resistin levels are increased in obese subjects and its concentrations are directly associated with IR $[4,57]$.

The miR-515 family has 51 members, and miR-519 belongs to this family. miR-519 has been found to be overexpressed in the SAT of individuals with morbid obesity. Transcription factor PPARa is a direct target of miR-519d [58]. PPARa regulates the expression of different genes involved in b-oxidation, such as carnitine palmitoyl transferase and acyl-CoA oxidase; its activation promotes FFA oxidation, which reduces IR [59]. miR-126 is repressed in SAT in obese individuals, and CCL2 is a direct target of this miRNA [15, 25, 27].

\section{Conclusions}

Obesity leads to an adipose tissue dysfunction that is responsible for metabolic alterations such as IR. Epigenetics could explain some of the molecular mechanisms responsible for adipose tissue dysfunction. miRNAs are small, single-stranded RNAs of endogenous expression, which regulate gene expression at a post-transcriptional level. miRNAs normally bind to a target mRNA, and the miRNA-mRNA interaction results in mRNA translation inhibition or degradation. Obesity is associated with changes in miRNA expression in adipose tissue, this leads to overexpression or repression of genes implicated in IR development. Figure 2 summarises the changes in miRNA expression in adipose tissue of obese subjects and their relationship with IR development. miRNAs have been proposed as possible biological markers and therapeutic targets in some diseases, such as obesity.

\section{Funding}

This work was partially supported by grants: FONDEC-UAQ-2019-FME-2020-03. P. Estrella-Ibarra was supported by graduate fellowships from CONACYT 516954.

\section{Conflict of interest}

The authors declare that they have no known competing financial interests or personal relationships that could have appeared to influence the work reported in this paper.

\section{References}

1. World Health Organization, Obesity and overweight, 2017. http://www. who.int/mediacentre/factsheets/fs311/en/ (10-Nov-2017).

2. Goossens GH. The role of adipose tissue dysfunction in the pathogenesis of obesity-related insulin resistance. Physiol Behav. 2008; 94(2): 206-218, doi: 10.1016/j.physbeh.2007.10.010, indexed in Pubmed: 18037457.

3. Castoldi A, Naffah de Souza C, Câmara NO, et al. The Macrophage Switch in Obesity Development. Front Immunol. 2015; 6: 637, doi: 10.3389/fimmu.2015.00637, indexed in Pubmed: 26779183.

4. Sadashiv I, Tiwari S, Paul BN, et al. Over expression of resistin in adipose tissue of the obese induces insulin resistance. World J Diabetes. 2012; 3(7): 135-141, doi: 10.4239/wjd.v3.i7.135, indexed in Pubmed: 22816026.

5. Klöting N, Graham TE, Berndt J, et al. Serum retinol-binding protein is more highly expressed in visceral than in subcutaneous adipose tissue and is a marker of intra-abdominal fat mass. Cell Metab. 2007; 6(1): 79-87, doi: 10.1016/j.cmet.2007.06.002, indexed in Pubmed: 17618858.

6. Ayina CN, Noubiap JJ, Etoundi Ngoa LS, et al. Association of serum leptin and adiponectin with anthropomorphic indices of obesity, blood lipids and insulin resistance in a Sub-Saharan African population. Lipids Health Dis. 2016; 15: 96, doi: 10.1186/s12944-016-0264-x, indexed in Pubmed: 27189377.

7. Harwood HJ. The adipocyte as an endocrine organ in the regulation of metabolic homeostasis. Neuropharmacology. 2012; 63(1): 57-75, doi: 10.1016/j.neuropharm.2011.12.010, indexed in Pubmed: 22200617.

8. Lafontan M. Adipose tissue and adipocyte dysregulation. Diabetes Metab. 2014; 40(1): 16-28, doi: 10.1016/j.diabet.2013.08.002, indexed in Pubmed: 24139247.

9. Dalmas E, Clément K, Guerre-Millo M. Defining macrophage phenotype and function in adipose tissue. Trends Immunol. 2011; 32(7): 307-314, doi: 10.1016/j.it.2011.04.008, indexed in Pubmed: 21616718.

10. Zou C, Shao J. Role of adipocytokines in obesity-associated insulin resistance. J Nutr Biochem. 2008; 19(5): 277-286, doi: 10.1016/j.jnutbio.2007.06.006, indexed in Pubmed: 18054218. 
11. Park JH, Kim SH, Lee MS, et al. Epigenetic modification by dietary factors: Implications in metabolic syndrome. Mol Aspects Med. 2017; 54 58-70, doi: 10.1016/j.mam.2017.01.008, indexed in Pubmed: 28216432.

12. Kim VN. MicroRNA biogenesis: coordinated cropping and dicing. Nat Rev Mol Cell Biol. 2005; 6(5): 376-385, doi: 10.1038/nrm1644, indexed in Pubmed: 15852042.

13. Bartel DP. MicroRNAs: genomics, biogenesis, mechanism, and function. Cell. 2004; 116(2): 281-297, doi: 10.1016/s0092-8674(04)00045-5, indexed in Pubmed: 14744438 .

14. Lewis BP, Burge CB, Bartel DP. Conserved seed pairing, often flanked by adenosines, indicates that thousands of human genes are microRNA targets. Cell. 2005; 120(1): 15-20, doi: 10.1016/j.cell.2004.12.035, indexed in Pubmed: 15652477.

15. Kulyté A, Belarbi Y, Lorente-Cebrián S, et al. Additive effects of microRNAs and transcription factors on CCL2 production in human white adipose tissue. Diabetes. 2014; 63(4): 1248-1258, doi: 10.2337/db13-0702, indexed in Pubmed: 24379347.

16. miRBase $\mathrm{v} 21$. miRBase: the microRNA database. http://www.mirbase. org/cgi-bin/browse.pl?org=hsa ( 02-Jul-2020).

17. Inui M, Martello G, Piccolo S. MicroRNA control of signal transduction. Nat Rev Mol Cell Biol. 2010; 11(4): 252-263, doi: 10.1038/nrm2868, indexed in Pubmed: 20216554.

18. Ipsaro JJ, Joshua-Tor L. From guide to target: molecular insights into eukaryotic RNA-interference machinery. Nat Struct Mol Biol. 2015; 22(1): 20-28, doi: 10.1038/nsmb.2931, indexed in Pubmed: 25565029.

19. Pasquinelli AE. MicroRNAs and their targets: recognition, regulation and an emerging reciprocal relationship. Nat Rev Genet. 2012; 13(4): 271-282, doi: 10.1038/nrg3162, indexed in Pubmed: 22411466.

20. Iwakawa HO, Iwakawa HO, Tomari Y. The Functions of MicroRNAs: mRNA Decay and Translational Repression. Trends Cell Biol. 2015; 25(11): 651-665, doi: 10.1016/j.tcb.2015.07.011, indexed in Pubmed: 26437588

21. Arner E, Mejhert N, Kulyté A, et al. Adipose tissue microRNAs as regulators of CCL2 production in human obesity. Diabetes. 2012; 61(8): 1986-1993, doi: 10.2337/db11-1508, indexed in Pubmed: 22688341

22. Brennan E, Wang Bo, McClelland A, et al. Protective Effect of let-7 miRNA Family in Regulating Inflammation in Diabetes-Associated Atherosclerosis. Diabetes. 2017; 66(8): 2266-2277, doi: 10.2337/db16-1405, indexed in Pubmed: 28487436.

23. Sung SY, Liao CH, Wu HP, et al. Loss of let-7 microRNA upregulates IL-6 in bone marrow-derived mesenchymal stem cells triggering a reactive stromal response to prostate cancer. PLoS One. 2013; 8(8): e71637, doi: 10.1371/journal.pone.0071637, indexed in Pubmed: 23977098.

24. Jones A, Danielson KM, Benton MC, et al. miRNA Signatures of Insulin Resistance in Obesity. Obesity (Silver Spring). 2017; 25(10): 1734-1744 doi: 10.1002/oby.21950, indexed in Pubmed: 28834285.

25. Santovito D, De Nardis V, Marcantonio P, et al. Plasma exosome microRNA profiling unravels a new potential modulator of adiponectin pathway in diabetes: effect of glycemic control. J Clin Endocrino Metab. 2014; 99(9): E1681-E1685, doi: 10.1210/jc.2013-3843, indexed in Pubmed: 24937531.

26. Meerson A, Traurig M, Ossowski V, et al. Human adipose microRNA-221 is upregulated in obesity and affects fat metabolism downstream of leptin and TNF- . Diabetologia. 2013; 56(9): 1971-1979, doi: 10.1007/s00125-013-2950-9, indexed in Pubmed: 23756832

27. Belarbi Y, Mejhert N, Lorente-Cebrián S, et al. MicroRNA-193b Controls Adiponectin Production in Human White Adipose Tissue. J Clin Endocrinol Metab. 2015; 100(8): E1084-E1088, doi: 10.1210/jc.2015-1530, indexed in Pubmed: 26020766.

28. Derosa G, Fogari E, D'Angelo A, et al. Adipocytokine levels in obese and non-obese subjects: an observational study. Inflammation. 2013; 36(4) 914-920, doi: 10.1007/s10753-013-9620-4, indexed in Pubmed: 23467997.

29. Guenther M, James R, Marks J, et al. Adiposity distribution influences circulating adiponectin levels. Transl Res. 2014; 164(4): 270-277, doi: 10.1016/j.trsl.2014.04.008, indexed in Pubmed: 24811003.

30. Lihn AS, Bruun JM, He G, et al. Lower expression of adiponectin mRNA in visceral adipose tissue in lean and obese subjects. Mol Cel Endocrinol. 2004; 219(1-2): 9-15, doi: 10.1016/j.mce.2004.03.002, indexed in Pubmed: 15149722

31. Yamauchi T, Kamon J, Minokoshi Y, et al. Adiponectin stimulates glucose utilization and fatty-acid oxidation by activating AMP-activated protein kinase. Nat Med. 2002; 8(11): 1288-1295, doi: 10.1038/nm788, indexed in Pubmed: 12368907.

32. Yoon MJ, Lee GY, Chung JJ, et al. Adiponectin increases fatty acid oxidation in skeletal muscle cells by sequential activation of AMP-activated protein kinase, p38 mitogen-activated protein kinase, and peroxisome proliferator-activated receptor alpha. Diabetes. 2006; 55(9): 2562-2570, doi: 10.2337/db05-1322, indexed in Pubmed: 16936205.

33. Park Sk, Oh SY, Lee MY, et al. CCAAT/enhancer binding protein and nuclear factor-Y regulate adiponectin gene expression in adipose tissue. Diabetes. 2004; 53(11): 2757-2766, doi: 10.2337/diabetes.53.11.2757, indexed in Pubmed: 15504955.
34. Senn JJ, Klover PJ, Nowak IA, et al. Interleukin-6 induces cellular insulin resistance in hepatocytes. Diabetes. 2002; 51(12): 3391-3399, doi: 10.2337/diabetes.51.12.3391, indexed in Pubmed: 12453891.

35. Rotter V, Nagaev I, Smith U. Interleukin-6 (IL-6) induces insulin resistance in 3T3-L1 adipocytes and is, like IL-8 and tumor necrosis factor-alpha, overexpressed in human fat cells from insulin-resistan subjects. J Biol Chem. 2003; 278(46): 45777-45784, doi: 10.1074/jbc. M301977200, indexed in Pubmed: 12952969.

36. Petersen EW, Carey AL, Sacchetti M, et al. Acute IL-6 treatment increases fatty acid turnover in elderly humans in vivo and in tissue culture in vitro. Am J Physiol Endocrinol Metab. 2005; 288(1): E155-E162, doi: 10.1152/ajpendo.00257.2004, indexed in Pubmed: 15383370.

37. Reilly SM, Saltiel AR. Adapting to obesity with adipose tissue inflammation. Nat Rev Endocrinol. 2017; 13(11): 633-643, doi: 10.1038/nrendo.2017.90, indexed in Pubmed: 28799554

38. Ortega FJ, Moreno-Navarrete JM, Pardo G, et al. MiRNA expression profile of human subcutaneous adipose and during adipocyte differentiation. PLoS One. 2010; 5(2): e9022, doi: 10.1371/journal.pone.0009022, indexed in Pubmed: 20126310.

39. Ortega FJ, Moreno M, Mercader JM, et al. Inflammation triggers specific microRNA profiles in human adipocytes and macrophages and in thei supernatants. Clin Epigenetics. 2015; 7: 49, doi: 10.1186/s13148-015-0083-3, indexed in Pubmed: 25926893.

40. Prats-Puig A, Ortega FJ, Mercader JM, et al. Changes in circulating microRNAs are associated with childhood obesity. J Clin Endocrinol Metab. 2013; 98(10): E1655-E1660, doi: 10.1210/jc.2013-1496, indexed in Pubmed: 23928666.

41. Ortega FJ, Mercader JM, Catalán V, et al. Targeting the circulating microRNA signature of obesity. Clin Chem. 2013; 59(5): 781-792, doi: 10.1373/clinchem.2012.195776, indexed in Pubmed: 23396142.

42. Wang YT, Tsai PC, Liao YC, et al. Circulating microRNAs have a sex-specific association with metabolic syndrome. J Biomed Sci. 2013; 20: 72, doi: 10.1186/1423-0127-20-72, indexed in Pubmed: 24093444.

43. Yamauchi T, Nio Y, Maki T, et al. Targeted disruption of AdipoR1 and AdipoR2 causes abrogation of adiponectin binding and metabolic ac tions. Nat Med. 2007; 13(3): 332-339, doi: 10.1038/nm1557, indexed in Pubmed: 17268472

44. Lustig Y, Barhod E, Ashwal-Fluss R, et al. RNA-binding protein PTB and microRNA-221 coregulate AdipoR1 translation and adiponectin signaling. Diabetes. 2014; 63(2): 433-445, doi: 10.2337/db13-1032, indexed in Pubmed: 24130336

45. Peng J, Zhou Y, Deng Z, et al. miR-221 negatively regulates inflammation and insulin sensitivity in white adipose tissue by repression of sirtuin-1 (SIRT1). J Cell Biochem. 2018; 119(8): 6418-6428, doi: 10.1002/jcb.26589, indexed in Pubmed: 29236311.

46. Cao Y, Jiang X, Ma H, et al. SIRT1 and insulin resistance. J Diabetes Complications. 2016; 30(1): 178-183, doi: 10.1016/j.jdiacomp.2015.08.022, indexed in Pubmed: 26422395

47. Yoshizaki T, Milne JC, Imamura T, et al. SIRT1 exerts anti-inflammatory effects and improves insulin sensitivity in adipocytes. Mol Cell Biol. 2009; 29(5): 1363-1374, doi: 10.1128/MCB.00705-08, indexed in Pubmed: 19103747

48. Shi Z, Zhao C, Guo X, et al. Differential expression of microRNAs in omental adipose tissue from gestational diabetes mellitus subjects reveals miR-222 as a regulator of ER expression in estrogen-induced insulin resistance. Endocrinology. 2014; 155(5): 1982-1990, doi: 10.1210/en.2013-2046, indexed in Pubmed: 24601884.

49. Kouidhi S, Berrhouma R, Rouissi K, et al. Human subcutaneous adipose tissue Glut 4 mRNA expression in obesity and type 2 diabetes. Acta Diabetol. 2013; 50(2): 227-232, doi: 10.1007/s00592-011-0295-8, indexed in Pubmed: 21604201.

50. Chuang TY, Wu HL, Chen CC, et al. MicroRNA-223 Expression is Upregulated in Insulin Resistant Human Adipose Tissue. J Diabetes Res. 2015, 2015: 943659, doi: 10.1155/2015/943659, indexed in Pubmed: 26273679.

51. Deiuliis JA, Syed R, Duggineni D, et al. Visceral Adipose MicroRNA 223 I Upregulated in Human and Murine Obesity and Modulates the Inflammatory Phenotype of Macrophages. PLoS One. 2016; 11(11): e0165962, doi: 10.1371/journal.pone.0165962, indexed in Pubmed: 27812198.

52. Lee EK, Lee MiJ, Abdelmohsen K, et al. miR-130 suppresses adipogenesis by inhibiting peroxisome proliferator-activated receptor gamma expression. Mol Cell Biol. 2011; 31(4): 626-638, doi: 10.1128/MCB.00894-10, indexed in Pubmed: 21135128.

53. Sharma AM, Staels B. Review: Peroxisome proliferator-activated receptor gamma and adipose tissue--understanding obesity-related changes in regulation of lipid and glucose metabolism. J Clin Endocrinol Metab. 2007; 92(2): 386-395, doi: 10.1210/jc.2006-1268, indexed in Pubmed: 17148564

54. Redonnet A, Bonilla S, Noël-Suberville C, et al. Relationship between peroxisome proliferator-activated receptor gamma and retinoic acid receptor alpha gene expression in obese human adipose tissue. Int J Obes Relat Metab Disord. 2002; 26(7): 920-927, doi: 10.1038/sj.ijo.0802025, indexed in Pubmed: 12080444. 
55. Kursawe R, Narayan D, Cali AMG, et al. Downregulation of ADIPOQ and PPAR 2 gene expression in subcutaneous adipose tissue of obese adolescents with hepatic steatosis. Obesity (Silver Spring). 2010; 18(10): 1911-1917, doi: 10.1038/oby.2010.23, indexed in Pubmed: 20168312.

56. Ishida M, Shimabukuro M, Yagi S, et al. MicroRNA-378 regulates adiponectin expression in adipose tissue: a new plausible mechanism. PLoS One. 2014; 9(11): e111537, doi: 10.1371/journal.pone.0111537, indexed in Pubmed: 25379946.

57. Liu L, Li Q, Xiao X, et al. miR-1934, downregulated in obesity, protects against low-grade inflammation in adipocytes. Mol Cell Endocrinol. 2016; 428: 109-117, doi: 10.1016/j.mce.2016.03.026, indexed in Pubmed: 27013351.
58. Martinelli R, Nardelli C, Pilone V, et al. miR-519d overexpression is associated with human obesity. Obesity (Silver Spring). 2010; 18(11): 2170-2176, doi: 10.1038/oby.2009.474, indexed in Pubmed: 20057369.

59. Guiu-Jurado E, Auguet T, Berlanga A, et al. Downregulation of de Novo Fatty Acid Synthesis in Subcutaneous Adipose Tissue of Moderately Obese Women. Int J Mol Sci. 2015; 16(12): 29911-29922, doi: 10.3390/ijms161226206, indexed in Pubmed: 26694359.

60. Heneghan HM, Miller N, McAnena OJ, et al. Differential miRNA expression in omental adipose tissue and in the circulation of obese patients identifies novel metabolic biomarkers. J Clin Endocrinol Metab. 2011; 96(5): E846-E850, doi: 10.1210/jc.2010-2701, indexed in Pubmed: 21367929 